\title{
Unfinished Agenda of Reforms
}

\section{Hafeez Sheikh*}

\begin{abstract}
This paper gives a brief overview of Pakistan's economic growth over the past decades and critically examines the economic policies of the last government. It draws attention to the unchecked state dominance across all sectors of the economy and emphasizes the need for further privatization. The paper concludes with some suggestions on the way forward towards growth and economic prosperity.
\end{abstract}

JEL Classification: L33, O43, Q58

Keywords: Privatization, Economic Policy, Economic Growth

\section{Introduction}

At present, the Pakistan economy is coming under threat. O1d problems, left unattended, are combining with emerging new ones. There is a real danger that if the government does not respond to the emerging economic challenges in a timely and resolute manner the macroeconomic situation could worsen significantly.

The topic of this paper, "An Unfinished Agenda of Reforms", is so broad that it is hard to limit it to any single area. The paper starts by drawing general lessons of international experience. It then reviews Pakistan's economic history, focusing on the recent past and the emerging difficulties. The conclusion gives some suggestions on the way forward. I believe that unless Pakistan can reorient, reduce and reform the role of the government in the economy, it is unlikely to sustain growth and improve the quality of life of its citizens.

Two general statements need to be made here: One is that these have been the best times the world has ever seen since the sixties: the best time in terms of growth and prosperity, in terms of expansion of trade and so on. The

\footnotetext{
Former Minister of Investment and Privatization, Government of Pakistan. I want to acknowledge the excellent assistance of Ms. Uzma Afzal (Lahore School of Economics) in the preparation of this paper.
} 
second point is that because of changes in technology and multiple linkages and interconnections, things are happening at an unprecedented pace. Events have a way of fast-forwarding. And third, we know that some people in a society may get lucky, but luck has a way of deserting the unprepared. This also applies to economic management, which requires high levels of preparedness, agility, capacity to respond speedily and ability to execute.

It can be said that the cause of Pakistan's looming difficulties is partly that for the past 18 months, the country has been in a slumber. Pakistan has been unable, or even unwilling to respond to the challenges, which have now multiplied and accumulated and begun to look ominous.

The thesis of this paper is that unless we transform and reorient the role of the government, it will be hard to get the results desired, and that policies requiring the government's proper functioning will suffer. Recommendations involving the government, not being implemented or poorly implemented, leave a trail of unfinished business, incomplete projects, abandoned schemes and wasted resources.

\section{Three Lessons of Development}

Let us start by asking ourselves what are the lessons of the past sixty years of development experience. What have we learnt in terms of what works and what does not? Or to put it a different way, why have some countries done well while others have been left behind? After all, sixty years back, many countries, newly free from colonial rule were roughly facing the same conditions. Pakistan's GDP for example was the same as that of Singapore. So which countries moved ahead and which were left behind, and why?

There are three major reasons behind the performance of countries:

Exports: Countries that found a way to sell their products to others got ahead, while those that could not, languished. So exports are a key determinant.

Education: Countries that focused on their citizens, on their human development and skill formation got ahead and those that ignored their citizens were left behind. In other words, you cannot have developed countries with underdeveloped people.

Private Sector: Countries that relied on governments to do everything, and there were 75-80 such countries - their economies ultimately collapsed. So while there is an obvious role for the state in the economy, it is not to do everything. And countries that assigned a primary role to the private sector and harnessed its energies were able to get ahead. 
In any long term strategy, these broad lessons - reliance on exports, education and the private sector - must guide us and shape our policies for sustainable development in the future.

\section{Review of History}

Table-1 gives a snapshot of Pakistan's economic history. It summarizes important facts about the country's economic development. Pakistan's economic history has had three growth spurts: the 1960s, 1980s and the 2000s, and all have a number of things in common.

The first (and disturbing) fact is that none of these growth spurts was sustained beyond 4-5 years. Second, they are all related to war: the Cold War, the Soviet-Afghan War and the War on Terror. Third, they have all been primarily driven by external capital inflows, particularly government-togovernment assistance. And when the inflows ended, so did the growth spurts.

Table-1: Key Facts of Pakistan

\begin{tabular}{|c|c|c|c|c|c|}
\hline Year & 1960s & 1970s & 1980s & 1990s & 2000s \\
\hline $\begin{array}{l}\text { GDP } \\
\text { Growth } \\
\text { Rate* }\end{array}$ & 6.8 & 4.8 & 6.9 & 4.6 & Approx. 5.4 \\
\hline Aid Status & $1^{\text {st }}$ Aid Episode & Aid Stoppage & $\begin{array}{l}2^{\text {nd }} \text { Aid } \\
\text { Episode }\end{array}$ & $\begin{array}{l}\text { Afghan War } \\
\text { Ends --Aid } \\
\text { Cut-Off }\end{array}$ & $\begin{array}{l}\text { 3rd Aid } \\
\text { Episode/ Debt } \\
\text { Rescheduling }\end{array}$ \\
\hline Drivers & $\begin{array}{l}\text { Factor } \\
\text { Accumulation }\end{array}$ & Populism & $\begin{array}{l}\text { Remittance } \\
\text { Led Boom }\end{array}$ & $\begin{array}{l}\text { Incomplete } \\
\text { IMF Prog/ } \\
\text { Foreign } \\
\text { Currency } \\
\text { Deposits Crisis }\end{array}$ & $\begin{array}{l}\text { Post 9/11 } \\
\text { Remittances }\end{array}$ \\
\hline $\begin{array}{l}\text { Important } \\
\text { Features } \\
(1)\end{array}$ & $\begin{array}{l}\text { Growing } \\
\text { Disparities }\end{array}$ & Nationalization & $\begin{array}{l}\text { Institutional } \\
\text { Deterioration }\end{array}$ & $\begin{array}{l}\text { Democracy / } \\
\text { Instability }\end{array}$ & $\begin{array}{l}\text { Successful IMF } \\
\text { Program /Macro } \\
\text { Consolidation }\end{array}$ \\
\hline (2) & $\begin{array}{l}\text { Political } \\
\text { Polarization }\end{array}$ & $\begin{array}{l}\text { Decline of Civil } \\
\text { Service }\end{array}$ & $\begin{array}{l}\text { Increase in } \\
\text { Military } \\
\text { Expenditure }\end{array}$ & $\begin{array}{l}\text { Perceptions of } \\
\text { Mis- } \\
\text { Governance }\end{array}$ & $\begin{array}{l}\text { Growing } \\
\text { Disparities }\end{array}$ \\
\hline (3) & $\begin{array}{l}\text { War and Civil } \\
\text { Disturbance }\end{array}$ & $\begin{array}{l}\text { Military Rule } \\
\text { After } 1977\end{array}$ & $\begin{array}{l}\text { Missed } \\
\text { Opportunity/ } \\
\text { Reforms } \\
\text { Postponed }\end{array}$ & $\begin{array}{l}\text { Banking } \\
\text { Reform } \\
\text { /Privatization } \\
\text { Efforts }\end{array}$ & $\begin{array}{l}\text { Banking } \\
\text { Reform/ } \\
\text { Privatization } \\
\text { Results }\end{array}$ \\
\hline (4) & $\begin{array}{l}\text { Planning } \\
\text { /PIDC }\end{array}$ & $\begin{array}{l}\text { Emphasis on } \\
\text { Government } \\
\text { Projects }\end{array}$ & $\begin{array}{l}\text { Expansion of } \\
\text { Public Sector }\end{array}$ & $\begin{array}{l}\text { Infrastructure } \\
\text { and Indepen- } \\
\text { dent Power } \\
\text { Producers }\end{array}$ & $\begin{array}{l}\text { Unsettled } \\
\text { Politics/Limited } \\
\text { Institutional } \\
\text { Reform }\end{array}$ \\
\hline
\end{tabular}

Source: Economic Survey 2006-07 
Pakistan has never been an attractive destination for foreign direct investment. These aid driven growth spurts curtailed the motivation - if there was any - of the country's leaders to try and fundamentally transform the economy. The dependence on agriculture remained unaltered while industrialization occurred with stunted growth and limited diversification. The dependence on primary (including cotton textiles) exports has resulted in a net export-import gap, which is increasing every year. Therefore, sustainable growth has never been achieved. This curtailed motivation and the lack of effort manifests itself most visibly in limited revenue mobilization. Government income from taxes remains less than $12 \%$ of GDP. Furthermore, even when the fiscal space was available, the money was not spent wisely (in tackling structural problems), and its efficiency of use was poor (in low-impact, corruption ridden, uncompleted government schemes). In addition, the role of the government has been excessive throughout the period. Finally, human capital development was never properly targeted and lagging regions were largely ignored resulting in, among other things, growing disparities.

A lot of this has to do with the nature of Pakistan's government; how it tries to do so much and ends up doing so little. Nonetheless, these growth spurts inevitably accompanied worsened distribution of income, conspicuous consumption and social stress.

\section{Recent Past - 3 Phases}

\section{1) Reformist (1999-2002)}

We will consider the recent past as the General Pervaiz Musharraf era. Within this time period, there are three distinct phases. The first can be called the 'reformist phase'. In my opinion, Musharraf felt that his rationale for being in power was to govern better than others. His early administration attempted to tackle the politically difficult - and longstanding - problems of the economy. People with good reputation and international reform experience were brought in. Efforts were made across the board to decentralize, and to manage finances better, especially at the level of the provinces, which had been a neglected area in the past. Some effort was made to mobilize taxes. A report was commissioned to suggest a methodology to make the government manageable and efficient. Deregulation and privatization were initiated and the business sector was involved in a dialogue on how to make the system more conducive to enhanced economic activity. The IMF program was adhered to and successfully completed. 


\section{2) Mixed Period (2002-2006)}

In the second phase, roughly corresponding to the period of the first three years of the political government, or around the end of 2002 to early 2006. This is a period in which the reforms were sustained in some areas, such as privatization for example. Some of the fiscal management policies remained sensible and yet it was seen that certain provincial governments began undoing the good work done earlier. The provincial devolution program itself came under assault by the provincial ministries. Both in the center and the provinces, political expediency took precedence over governance and with the changed international circumstances money began to flow in.

This flow of easy money had a profoundly negative consequence for reforms as it provided the cushion for complacency, fiscal extravagance and a premature and misplaced sense of self-congratulation. This "income effect" of aid, contributed towards irresponsible management, just when we had the growth momentum and we could have put the economy on a long run sustainable path.

\section{3) Drift, Reversal/Inaction (2006-2008)}

The last two years can be considered as the years of gradual drift. Fiscal extravagance became the norm; a self-congratulatory tone crept in. Difficult, and even not so difficult decisions, were postponed. Issues of ultra importance to the country remained unsettled even though their settlement was within grasp.

Thus Pakistan had an unsteady domestic situation and this coincided with external events that were both good and bad: good, because the regional economy had been in a very dynamic state. India, China, Iran, the Gulf countries were experiencing unprecedented growth and economic activity. ${ }^{1}$ At the same time, other events happening in the global economy threatened Pakistan's fragile gains. Some of these adverse developments were the increases in the prices of oil and agricultural commodities. Pakistan's response to these changes has been hardly adequate.

Policies, which needed to be sharply tailored, remained static. The absolute requirement for domestic adjustment to the price of oil was

\footnotetext{
${ }^{1}$ China for example, did what no country could do in history: achieve sustained double digit growth rates for over twenty five years. Despite being an ally and geographically connected to China, we have failed to leverage this dramatic economic development next door.
} 
ignored. Similarly, the potential for benefiting from the agricultural boom was not realized. These lapses created difficulties for the incoming government and made the process of adjustment more painful for the economy. Some of the emerging difficulties of Pakistan's economy are summarized in Table-2. These just give a snapshot of the economy's alarming condition.

Table-2: Deteriorating Fundamentals of 2007-08

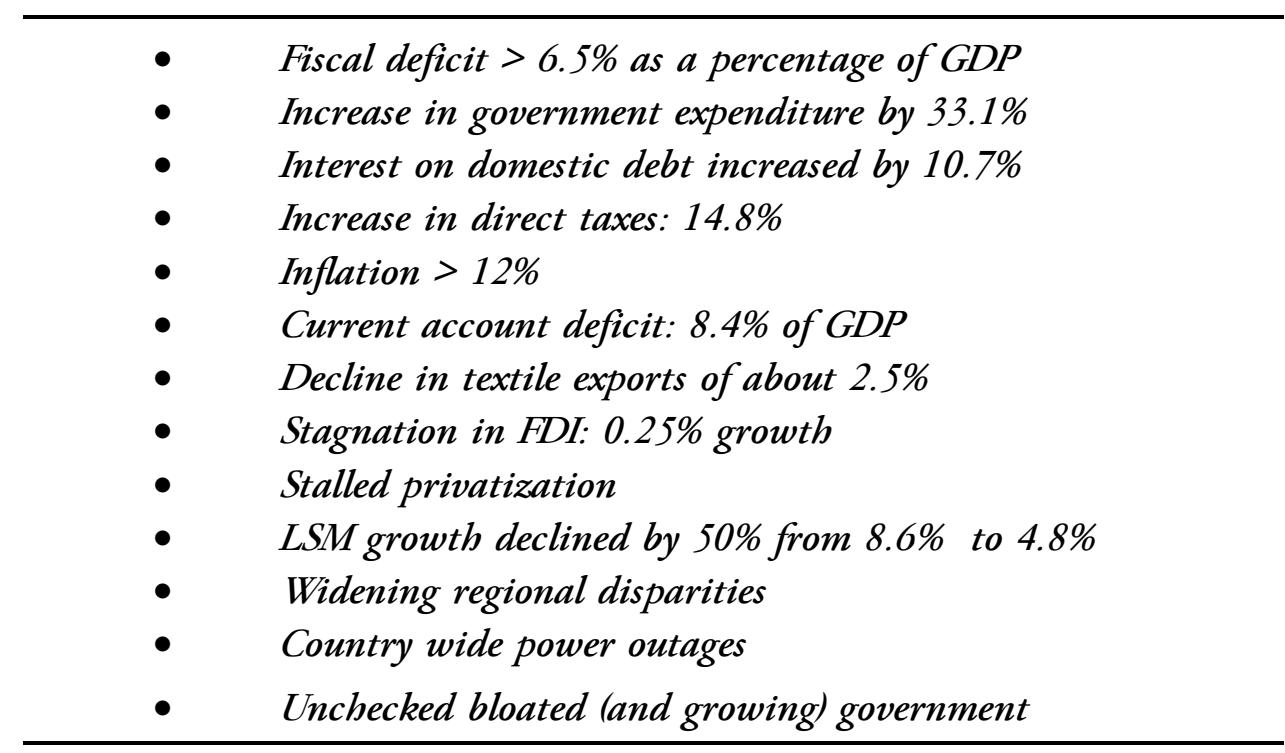

Source: Pakistan Economic Survey 2007-08

\section{Excessive Role of Government}

Returning to the thesis statement, the key issue is the need for reorienting, reducing and reforming the government. The defining point for this discussion is that the role for government is crucial, but it should not be all encompassing, as in the case of Pakistan. This role must be defined and its limits ought to be clearly marked.

Successive governments have tried to reduce the government's role in the commercial industrial sectors through privatization. Figure-1 shows the results of the success of privatization under different periods. The figures are only until 2005-06 as no activity has taken place since then. This gives further evidence of the diminished resolve on the reform front in the last two years. Huge progress was made in this area during the three year period of 2002-05, when 34 transactions worth $\$ 5$ billion were concluded in a transparent manner. 
However, this momentum was not sustained and almost all areas of the economy remained under state domination.

Figure-1: Privatization Receipts 1991-2005

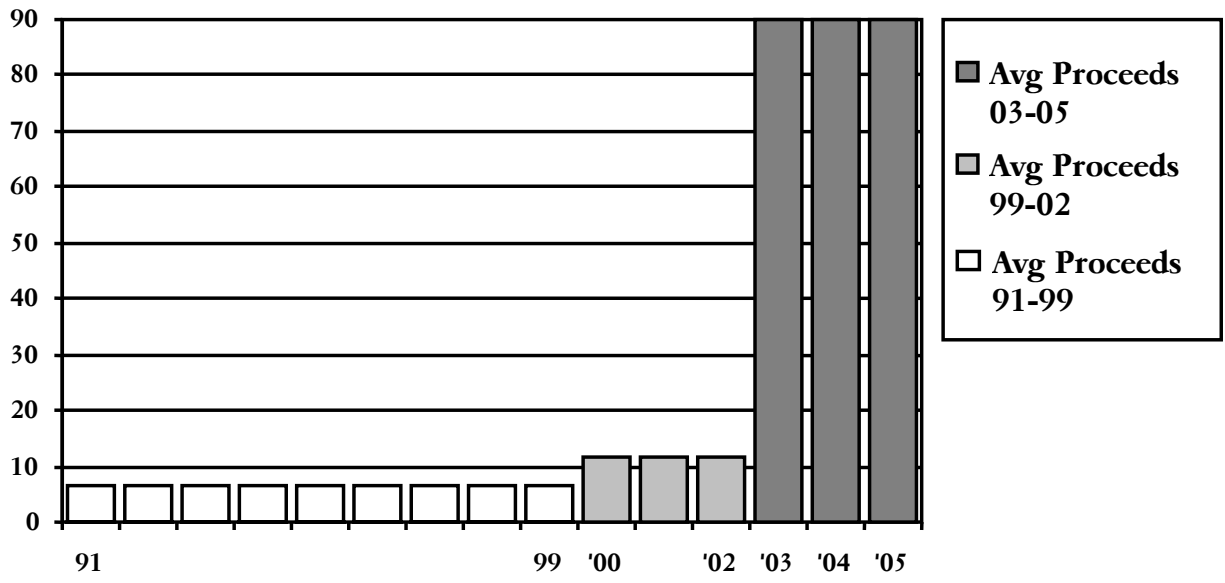

Source: Author's Estimates

The unchecked dominance of the state and the multiple roles it plays in virtually every sector of the economy is highlighted in Table-3. The first column lists all the sectors of the economy and the other columns specify the four separate dimensions of state involvement. The first is policy making. This is extremely important as a domain for the government. Effective policy making is much needed for the government to achieve its goals. The second is regulation. Expert opinion insists that regulation should be performed by independent or quasi-independent bodies. However, what happens is that government ministers and officials in the ministries are constantly intervening and meddling in regulatory matters so that the independence of many of these regulatory bodies is only on paper. The third column reflects the ownership, and once again it is evident that the state owns companies and assets in virtually all sectors of the economy. Of course, it is conceivable that some government ownership may be necessary for a limited period of time in some selected sectors. But what we find here is government ownership of entities in almost every single sector of the economy, with the associated opportunity cost. The final column shows management and here again we find that government bureaucrats are busy (or not very busy) managing companies in every sector of the economy. Bureaucrats with no training, experience or temperament in business, who are one day running the department of Haj Affairs are next day running some high-tech industry; one day they are joint secretary social welfare department and next day they find themselves running a steel mill or a fertilizer plant. 
Table-3: All-Pervasive Government

\begin{tabular}{|c|c|c|c|c|}
\hline Sector & Policy & Regulation & Ownership & Management \\
\hline Telecom & $\checkmark$ & $\checkmark$ & $\checkmark$ & \\
\hline Electricity & $\checkmark$ & $\checkmark$ & $\checkmark$ & $\checkmark$ \\
\hline Steel & $\checkmark$ & $\checkmark$ & $\checkmark$ & $\checkmark$ \\
\hline Aviation & $\checkmark$ & $\checkmark$ & $\checkmark$ & $\checkmark$ \\
\hline Banking & $\checkmark$ & $\checkmark$ & $\checkmark$ & $\checkmark$ \\
\hline Gas & $\checkmark$ & $\checkmark$ & $\checkmark$ & $\checkmark$ \\
\hline Water & $\checkmark$ & $\checkmark$ & $\checkmark$ & $\checkmark$ \\
\hline Petrol Stations & $\checkmark$ & $\checkmark$ & $\checkmark$ & $\checkmark$ \\
\hline Insurance & $\checkmark$ & $\checkmark$ & $\checkmark$ & $\checkmark$ \\
\hline Manufacturing & $\checkmark$ & $\checkmark$ & $\checkmark$ & $\checkmark$ \\
\hline Retail Shops & $\checkmark$ & $\checkmark$ & $\checkmark$ & $\checkmark$ \\
\hline Extraction (Mining) & $\checkmark$ & $\checkmark$ & $\checkmark$ & $\checkmark$ \\
\hline Ports & $\checkmark$ & $\checkmark$ & $\checkmark$ & $\checkmark$ \\
\hline Airports & $\checkmark$ & $\checkmark$ & $\checkmark$ & $\checkmark$ \\
\hline Real Estate Management & $\checkmark$ & $\checkmark$ & $\checkmark$ & $\checkmark$ \\
\hline Land Management & $\checkmark$ & $\checkmark$ & $\checkmark$ & $\checkmark$ \\
\hline Asset Management & $\checkmark$ & $\checkmark$ & $\checkmark$ & $\checkmark$ \\
\hline Tourism/Hotels & $\checkmark$ & $\checkmark$ & $\checkmark$ & $\checkmark$ \\
\hline Provincial Banks & $\checkmark$ & $\checkmark$ & $\checkmark$ & $\checkmark$ \\
\hline Trucking & $\checkmark$ & $\checkmark$ & $\checkmark$ & $\checkmark$ \\
\hline Construction & $\checkmark$ & $\checkmark$ & $\checkmark$ & $\checkmark$ \\
\hline Railway & $\checkmark$ & $\checkmark$ & $\checkmark$ & $\checkmark$ \\
\hline Farms/Agriculture & $\checkmark$ & $\checkmark$ & $\checkmark$ & $\checkmark$ \\
\hline Shipyard & $\checkmark$ & $\checkmark$ & $\checkmark$ & $\checkmark$ \\
\hline Shipping & $\checkmark$ & $\checkmark$ & $\checkmark$ & $\checkmark$ \\
\hline Holding Corporations & $\checkmark$ & $\checkmark$ & $\checkmark$ & $\checkmark$ \\
\hline Consultancy Services & $\checkmark$ & $\checkmark$ & $\checkmark$ & $\checkmark$ \\
\hline Engineering Goods & $\checkmark$ & $\checkmark$ & $\checkmark$ & $\checkmark$ \\
\hline Electrical Equipments & $\checkmark$ & $\checkmark$ & $\checkmark$ & $\checkmark$ \\
\hline
\end{tabular}


Therefore, it can be said that while it appears that a lot has been done in the area of privatization, in reality, very little has been accomplished. In fact, the government continues to be massively and unproductively engaged in industry, while ignoring its primary areas of responsibility. Thus there is a lot of unfinished work to be done in this reform area.

The key reform issue is that with the government proliferating in every area, and being so stretched, will it have time to make sensible policies? If government officials are busy trying to do everything else, who will do their jobs? (See Box 1) If the government machinery does not work, all recommendations will be futile.

\section{Box 1: Busy Bureaucrats}

I will give a personal example of the excessive role of government. When I was the Minister for Finance and Planning in Sindh, I noticed that the Additional Chief Secretary (who heads the Planning and Development Department) was tremendously busy and traveling all the time. So I asked him to make a list of all the committees that he was chairing. It turned out that he was the chairman of 147 committees. Now if you allow for all the holidays and leaves and traveling to Islamabad and back, there is hardly any time left for one meeting per year per committee. Clearly no serious issue can be tackled in this way and the results of government performance are proof of this overreach.

The extent of government pervasiveness and its ineffectiveness can be seen from the following example: The fisheries sector in Pakistan has about thirty different agencies involved in its functioning. These comprise of about thirteen different ministries, departments and agencies at the federal level, and eighteen at the provincial level. At least seven ministries and departments are in direct control of the sector. What is the outcome of this? A newspaper headline stating: "EU bans seafood from Pakistan."

\section{What to do}

It is important, at the outset to recognize that a successful development strategy - and its implementation - requires that we do many things right.

A few years ago the World Bank had convened some of the economic gurus, practitioners and analysts to talk about some of the lessons they had learnt from their participation and study of the development experience of the 1990s. A consensus appeared on the central role of 
institutions in sustaining development. The following quote from Larry

Summers, President, Harvard University, helps summarize this view:

"(an) overwhelming lesson... We have learned in the 1990s, is ... the transcendent importance of the quality of institutions and ... the efficacy of political administration.”

I think for a new government - any new government - the first thing to be done is to signal intentions. To convey, in an effective way, to the economic stakeholders - both domestic and international - that they are serious, that they mean business. These signals have to be communicated through actions and not speeches. In today's 'cut and paste' world, everyone is making the speech from the same hard disk, and economic agents heavily discount speeches of policy makers focusing almost exclusively on their deeds. The action areas that will most effectively communicate the government's intentions in the early part of their tenure and help rally the confidence and support of the economic stakeholders are discussed below. Undoubtedly, if the government takes early and serious action in these areas, it will be a good start and set the platform to build upon.

\section{1) Tackle Bloated Government}

The first and most important signal we can send is to tackle the bloated government. Every single reform has to start with that. Pakistan, for a long period had 32 ministries and then all of a sudden, the number was increased to 71 . At the least we should go back to having 32 ministries. This paper will avoid getting into details in this regard. It is common knowledge that there is a lot of waste and unproductive expenditure and cutting that in an efficient manner is at the heart of signaling, as well as fiscal management.

\section{2) Reform Annual Development Program}

The Annual Development Program (ADP) - which many think has little to do with actual development, but has a lot to do with people in positions of power, bureaucrats and contractors and their friends to make money. Because of the fiscal space of the last few years, these ADPs have expanded with the mushrooming of ill-advised, politically motivated schemes. It is imperative that such schemes are checked in order to control government waste.

It is necessary to get a handle on the ADP, as it is mostly a colossal waste of resources with very little impact in terms of real development or affecting the quality of life of Pakistan's citizens. The new government can 
send a very strong signal by reforming this area of unchecked governance (See Box 2).

\title{
Box 2: The ADP: A Need for Reform
}

\begin{abstract}
When I started working in the Finance Ministry in Sindh, I discovered that there were roughly 1100 schemes as part of the ADP. And I can say without exaggeration that hardly any scheme - apart from some roads (of poor quality) - ever were successfully completed. And I am willing to challenge anyone to show me that even ten percent of the thousands of schemes launched over the last 60 years were actually completed, and are operational.
\end{abstract}

In one district HQ, Jacobabad, there is a water scheme that has been going on for the last twenty years and still it is not completed. The President, the Prime Minister, the Senate Chairman, all have inaugurated it, yet, it is still not operational.

Again, to go back to my own personal experience, during my first year in Sindh, we focused on completing projects instead of starting new ones as part of the reforms. A few schemes were actually completed out of the 1153 schemes on the books. Nonetheless, I recently met a senior official of the Sindh Government and asked him about the number of ADP schemes which were currently in place. His answer was: 7500.

The situation is no different at the Center. We were at National Economic Council (NEC) about two years back; the NEC is the highest economic decision making body where the ADPs get approved. The Prime Minister and virtually every important person in the government attends the NEC. You are given a document of around a thousand pages ten minutes before the meeting in which the ADP is approved. All these schemes are mentioned in these pages. These schemes are finalized based on cursory glances at their contexts and are passed on by the cabinet. In a one page summary, it shows how much money is allocated to a given sector, the next column shows the allotted budget, another column is about how much has been released and the final column explains how much is being actually utilized.

I would like to quote an interesting case of the water sector. About 290 billion rupees had been allocated for the water projects, the summary showed that 10 billion had been released and that in three quarters of the year, 2 billion had been spent. I raised the point that at this rate, spending two billion per year on projects totaling 290 billion would mean that the time required to complete them would be 145 years. 


\section{3) Privatize, Deregulate and Involve Private Sector in Infrastructure}

Upgradation of the infrastructure - especially electricity productionis an important area for further development. The failures of previous governments in this area have created a crisis situation both for the economy and the new government. However, it is important to note that if, in order to address the problem, the government resorts to public sector projects via the ADP, it will undoubtedly result in failure. The private sector must be given incentive to invest its capital in the creation of infrastructure; and the role of the government should be limited to policy making and designing of these incentives.

\section{Conclusion}

Let me end this paper by giving a very simple yet inspiring example of how technology has advanced in Pakistan, despite its political and economic shortcomings. This will reveal my optimism and suggest that things can be done if we adopt the right approach. Fifteen years back, getting a telephone connection meant waiting for years. Now, in 2008, it only takes a few minutes. So I want you to think about it. What once sounded like an insurmountable problem was tackled simply by having sensible policies, with the right policy mix, reorientation of the role of the government and the private sector along with appropriate incentives. The lesson - an optimistic one- is that it can be done. 